\title{
LIST of the PRESENT OFFICERS of the SOCIETY.
}

\author{
T H E K I G PATRON.
}

The Right Honourable the Earl of Bute, Prefident:-

His Grace the Duke of Montrofe, Firlt Vice-Prefident.

The Right Honourable Lord Monboddo,

Alexander Wight, Efq;

$\left.\begin{array}{l}\text { William Tytler of Woodfiouflee, Efq; } \\ \text { Alexander Ferguffon of Craigdarroch; Efq; }\end{array}\right\}$ Vice-Prefidents.

Sir William Forbes of Pittifigo, Baroniet, Tteafurer.

John Gardner, Efq; Caffiter.

Mr James Cummyng, Secretary.

The Rev Dr Jolun Geddes, Secretary for Forcigni Cotrếppondence.

Mr Alexander Mathiefon; Latin Secretary.

Mr Alexander Drummoind, French Secretary.

The Rev Mr Jofeph Robertfon M`Gregor, Gaelic Secretary.

Mr William Smellie, Superintendant of Natural Hiftory.

The Rev. Dr John Geddes,

Dr William Farquharfon,

Mr Rober Kerr, Cenfors.

Mr William Smellie,

$\left.\begin{array}{l}\text { Mr Alerander Keith, } \\ \text { Mr John Dundas, }\end{array}\right\}$ Auditors of Accompts.

William Charles leittle of Libfortoth; Efq

Alexander Fergufton of Craigdarroch, Efq;

Mr John Dundas,

Mr Gíorge Fator,

Mr William Smellie,

of the Council:

Df Wintal Fà Tularfon

Mr James Cummyng,

William Charles Little of Libberton, Efq;

Dr William Farquharfon,

Curators:

John Spottifwoode, Efq; Agrent at London.

Mr George Cairncrofs, Agent at Ediaburgh.

William Mylne, Macer. 